Boise State University

ScholarWorks

$10-2013$

\title{
Megathrust Splay Faults at the Focus of the Prince William Sound Asperity, Alaska
}

\author{
Lee M. Liberty \\ Boise State University \\ Shaun P. Finn \\ Boise State University \\ Peter J. Haeussler \\ United States Geological Survey - Anchorage \\ Thomas L. Pratt \\ U.S. Geological Survey - Reston \\ Andrew Peterson \\ Boise State University
}




\title{
Megathrust splay faults at the focus of the Prince William Sound asperity, Alaska
}

\author{
Lee M. Liberty, ${ }^{1}$ Shaun P. Finn, ${ }^{1}$ Peter J. Haeussler, ${ }^{2}$ Thomas L. Pratt, ${ }^{3}$ \\ and Andrew Peterson ${ }^{1}$ \\ Received 30 April 2013; revised 6 September 2013; accepted 10 September 2013; published 17 October 2013.
}

[1] High-resolution sparker and crustal-scale air gun seismic reflection data, coupled with repeat bathymetric surveys, document a region of repeated coseismic uplift on the portion of the Alaska subduction zone that ruptured in 1964. This area defines the western limit of Prince William Sound. Differencing of vintage and modern bathymetric surveys shows that the region of greatest uplift related to the 1964 Great Alaska earthquake was focused along a series of subparallel faults beneath Prince William Sound and the adjacent Gulf of Alaska shelf. Bathymetric differencing indicates that $12 \mathrm{~m}$ of coseismic uplift occurred along two faults that reached the seafloor as submarine terraces on the Cape Cleare bank southwest of Montague Island. Sparker seismic reflection data provide cumulative Holocene slip estimates as high as $9 \mathrm{~mm} / \mathrm{yr}$ along a series of splay thrust faults within both the inner wedge and transition zone of the accretionary prism. Crustal seismic data show that these megathrust splay faults root separately into the subduction zone décollement. Splay fault divergence from this megathrust correlates with changes in midcrustal seismic velocity and magnetic susceptibility values, best explained by duplexing of the subducted Yakutat terrane rocks above Pacific plate rocks along the trailing edge of the Yakutat terrane. Although each splay fault is capable of independent motion, we conclude that the identified splay faults rupture in a similar pattern during successive megathrust earthquakes and that the region of greatest seismic coupling has remained consistent throughout the Holocene.

Citation: Liberty, L. M., S. P. Finn, P. J. Haeussler, T. L. Pratt, and A. Peterson (2013), Megathrust splay faults at the focus of the Prince William Sound asperity, Alaska, J. Geophys. Res. Solid Earth, 118, 5428-5441, doi:10.1002/jgrb.50372.

\section{Introduction}

[2] Insights regarding subduction zone processes and hazards can be derived from documenting fault distribution, fault slip, and the recurrence intervals of great earthquakes. The 1964 M9.2 Great Alaska earthquake was the second largest earthquake ever recorded. The earthquake rupture extended over an area approximately $800 \mathrm{~km}$ long by $250 \mathrm{~km}$ wide and generated tsunamis that devastated local communities across southern Alaska and damaged distant communities along the North American coast (Figure 1) [Plafker, 1969]. The earthquake initiated beneath the area immediately north of Prince William Sound (PWS) but ruptured across a region of low seismic coupling to activate a second asperity near Kodiak Island [e.g., Plafker, 1969; Christensen and Beck, 1994; Johnson et al., 1996; Zweck et al., 2002; Suito and Freymueller, 2009]. Here we examine deformation of the young sediment apron that lies above this subduction zone system to

\footnotetext{
${ }^{1}$ Boise State University, Department of Geosciences, Boise, Idaho, USA

${ }^{2}$ United States Geological Survey, Anchorage, Alaska, USA.

${ }^{3}$ United States Geological Survey, Reston, Virginia, USA.

Corresponding author: L. M. Liberty, Boise State University, Department of Geosciences, 1910 University Drive, Boise, ID 83725, USA. (lliberty@boisestate.edu)

(C)2013. American Geophysical Union. All Rights Reserved. 2169-9313/13/10.1002/jgrb.50372
}

document the cumulative slip distribution for earthquakes over the past $10-15 \mathrm{kyr}$. We show that the surface faulting from the 1964 earthquake was typical of great millennialscale earthquakes in this region and that the area with the greatest documented seismic coupling [Zweck et al., 2002] has remained consistent for most Holocene earthquakes.

[3] The 1964 rupture had two high moment release areas with about $21 \mathrm{~m}$ of slip beneath PWS and $15 \mathrm{~m}$ of slip near Kodiak Island [Johnson et al., 1996]. The megathrust beneath PWS is the contact between the subducting Yakutat terrane and the overlying accretionary complex, referred to as the Prince William terrane [Brocher et al., 1994]. West of Montague Island, the subducting Yakutat slab is absent and the Pacific Plate subducts directly beneath the North American plate [e.g., Brocher et al., 1994; EberhartPhillips et al., 2006]. The PWS asperity, defined as a region of high moment release [e.g., Lay et al., 1982; Scholz and Campos, 2012], was centered beneath the southwest end of Montague Island near a prominent magnetic high that defines the western boundary of the subducted Yakutat terrane (Figure 1) [Bruns, 1983; Griscom and Sauer, 1990; Brocher et al.; 1994; Johnson et al., 1996; Zweck et al., 2002; Eberhart-Phillips et al., 2006].

[4] The Yakutat microplate is moving north-northwest approximately $50 \mathrm{~mm} / \mathrm{yr}$ relative to North America while the Pacific plate is subducting in a slightly more northerly direction at $51 \mathrm{~mm} / \mathrm{yr}$ (Figure 1) [Elliott et al., 2010]. The 


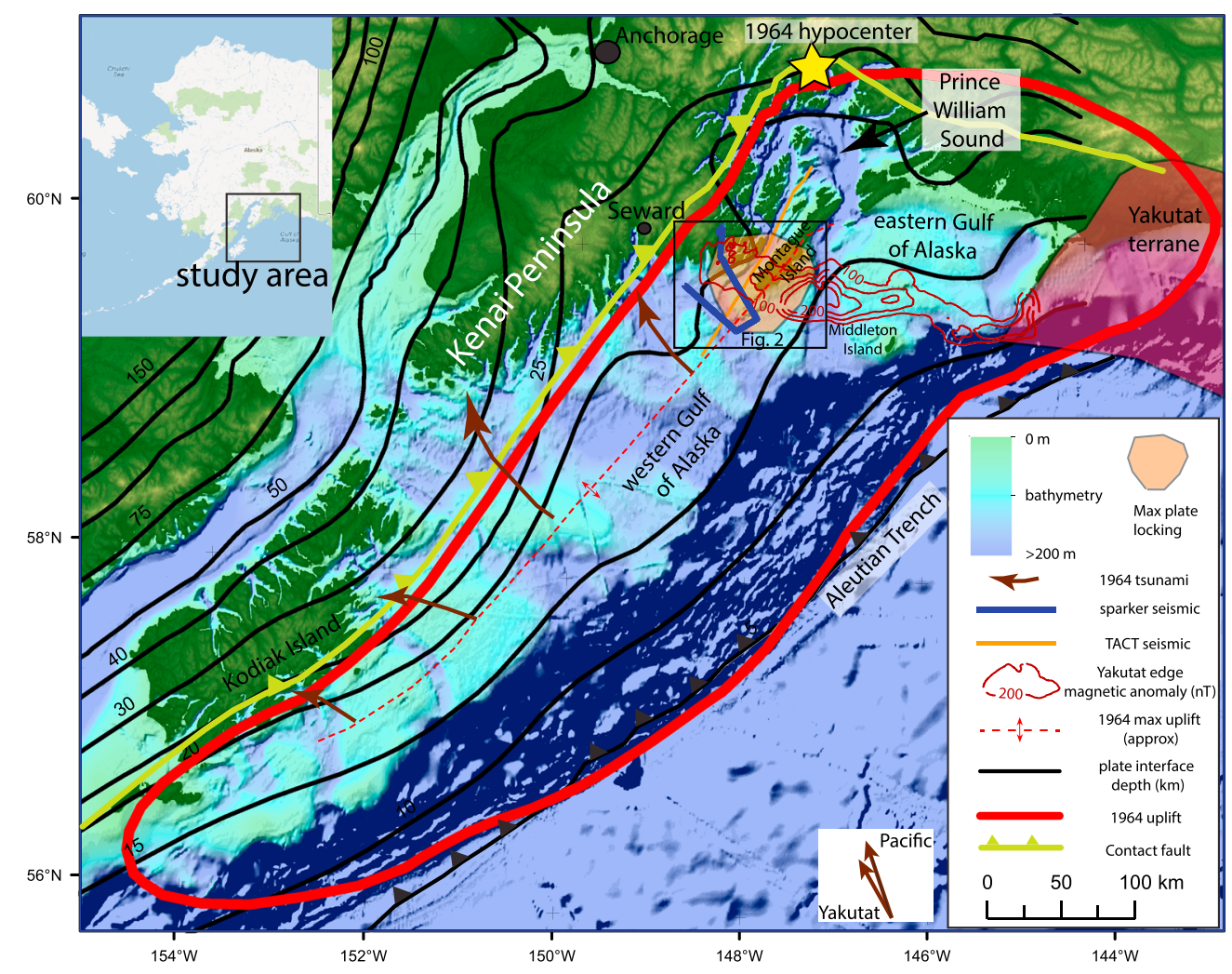

Figure 1. Study area map from southern Alaska showing bathymetry, contours of depth to the top of the seismogenic zone [from Zweck et al., 2002], uplift region and tsunami source (estimated) and run up from 1964 earthquake [from Plafker, 1969], edge of subducted Yakutat terrane as defined by a prominent magnetic anomaly, and location of sparker and TACT seismic profiles discussed in text. Note the deflection in the depth to the seismogenic zone in Prince William Sound that results from Yakutat terrane subduction. The box shows the study area focus that is presented in Figure 2.

Yakutat microplate is relatively buoyant, which results in a subduction angle of approximately $3^{\circ}$ beneath PWS compared to the steeper $8^{\circ}$ dip along the Kodiak segment [e.g., Brocher et al., 1994; Eberhart-Phillips et al., 2006; Doser and Veilleux, 2009]. The maximum slip from the 1964 earthquake was largely coincident with the southwestern edge of the subducted Yakutat terrane, which appears to be largely coupled to the underlying Pacific plate [Zweck et al., 2002; Doser et al., 2004; Eberhart-Phillips et al., 2006; Ichinose et al., 2007]. Geodetic measurements in the PWS area show movement at the Pacific-North America plate rate, which indicates a completely locked asperity [Zweck et al., 2002] with repeat times for large megathrust earthquakes of 330900 years (summary in Carver and Plafker [2008]). This locked asperity lies adjacent to a region of very low seismic coupling along the Kenai Peninsula that may accommodate plate convergence mostly by aseismic slip [e.g., Zweck et al., 2002].

[5] Here we interpret bathymetric and seismic profiles that were acquired in the Gulf of Alaska (Figure 1). First, we compare pre- and post-1964 bathymetric data from offshore Montague and Latouche Islands at the western margin of PWS to examine the uplift pattern during the 1964 earthquake. Bathymetric differencing has been used to document uplift from the 1964 Great Alaska earthquake [Malloy, 1964] and the 2011 Tohoku earthquake [Fujiwara et al., 2011]. Although Malloy used the same pre-earthquake data set as our study, their postearthquake analysis was limited to seven short profiles acquired southwest of Montague Island. The Tohoku analysis utilized two relatively modern multibeam bathymetric surveys. In our case, we examine differences between bathymetric surveys from the 1920s and regional seafloor surveys acquired in 1965 and 2004 (Figure 2). Although bathymetric surveys acquired prior to modern GPS navigation contain large positioning errors, vertical and horizontal controls for the hydrography of two older surveys were considered quite strong and show a clear pattern of coseismic uplift [Malloy, 1964]. We then use new high-resolution sparker seismic reflection data that we collected to interpret the postglacial tectonic and depositional history of the area across the active splay faults (Figures 1 and 2). These seismic profiles show sediment deformation across the inner wedge and transition zone regions of the accretionary prism [e.g., Wang and Hu, 2006; Kimura et al., 2007] and show the relationship between bathymetric lineations and active faults. Finally, we present a deep crustal seismic reflection profile across the presumed edge of the subducted Yakutat terrane beneath Montague Strait that was collected as part of the 1988 Trans-Alaska Crustal Transect (TACT) survey. These data show strong reflectivity from the subduction décollement and document multiple independent splay faults that surface from this megathrust. We interpret our bathymetric differencing results as indicating that these splay faults ruptured during the 1964 earthquake and the 

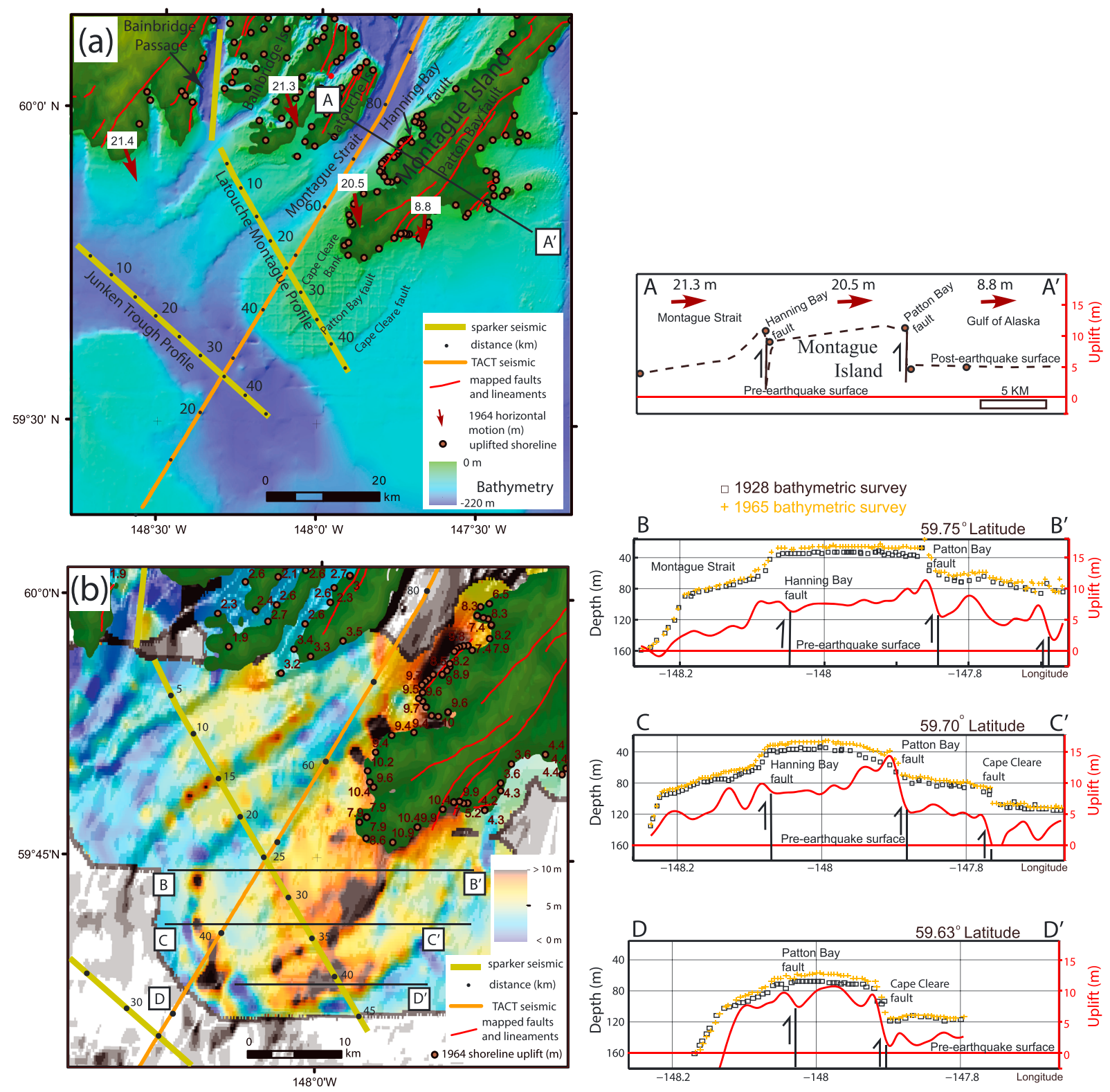

Figure 2. (a) Bathymetric map for the Montague Island area showing seismic profile locations, post-1964 shoreline uplift (circles) and horizontal motion and direction (arrows), and mapped faults [from Wilson and Hults, 2012]. (b) Bathymetric difference map showing uplift from 1964 earthquake and shoreline uplift values [from Plafker, 1969]. To the right, uplift profiles along four transects using bathymetric and shoreline data. Profile A-A' shows uplift across Montague Island (revised from Plafker [1969]). Left axis (black) represents water depth and right axis (red) represents uplift difference. Bathymetry data from a 1928 survey (black squares) are compared to a 1965 survey (gold plusses). Interpreted fault motion is shown on each cross section.

seismic data as indicating that although these splays independently root in the megathrust, the faults have ruptured during most Holocene megathrust earthquakes.

\section{The $M_{\mathrm{w}} \mathbf{9 . 2} 1964$ Earthquake and Related Uplift}

[6] The $1964 M_{\mathrm{w}} 9.2$ Great Alaska earthquake initiated north of PWS at a depth of about $25 \mathrm{~km}$ (Figure 1). The hypocenter was at the top of the Wadati-Benioff zone of seismicity. This depth also correlates with a boundary showing a large seismic velocity contrast [e.g., Brocher et al., 1994;
Oleskovich, et al., 1999; Doser and Veilleux, 2009; Fuis et al., 2008]. The earthquake initiated at the zone between the downgoing Yakutat and Pacific plates, but rupture propagated along splay faults through the subducted Yakutat terrane and overlying accretionary complex [Plafker, 1969; Brocher et al., 1994; Eberhart-Phillips et al., 2006; Fuis et al., 2008]. The earthquake shifted portions of PWS southeast as much as $21 \mathrm{~m}$ and lifted portions of the region more than $12 \mathrm{~m}$ (Figure 2) [Plafker, 1969]. Surface uplift as great as $7 \mathrm{~m}$ was documented across the Patton Bay fault on southwestern Montague Island, with additional surface uplifts of 

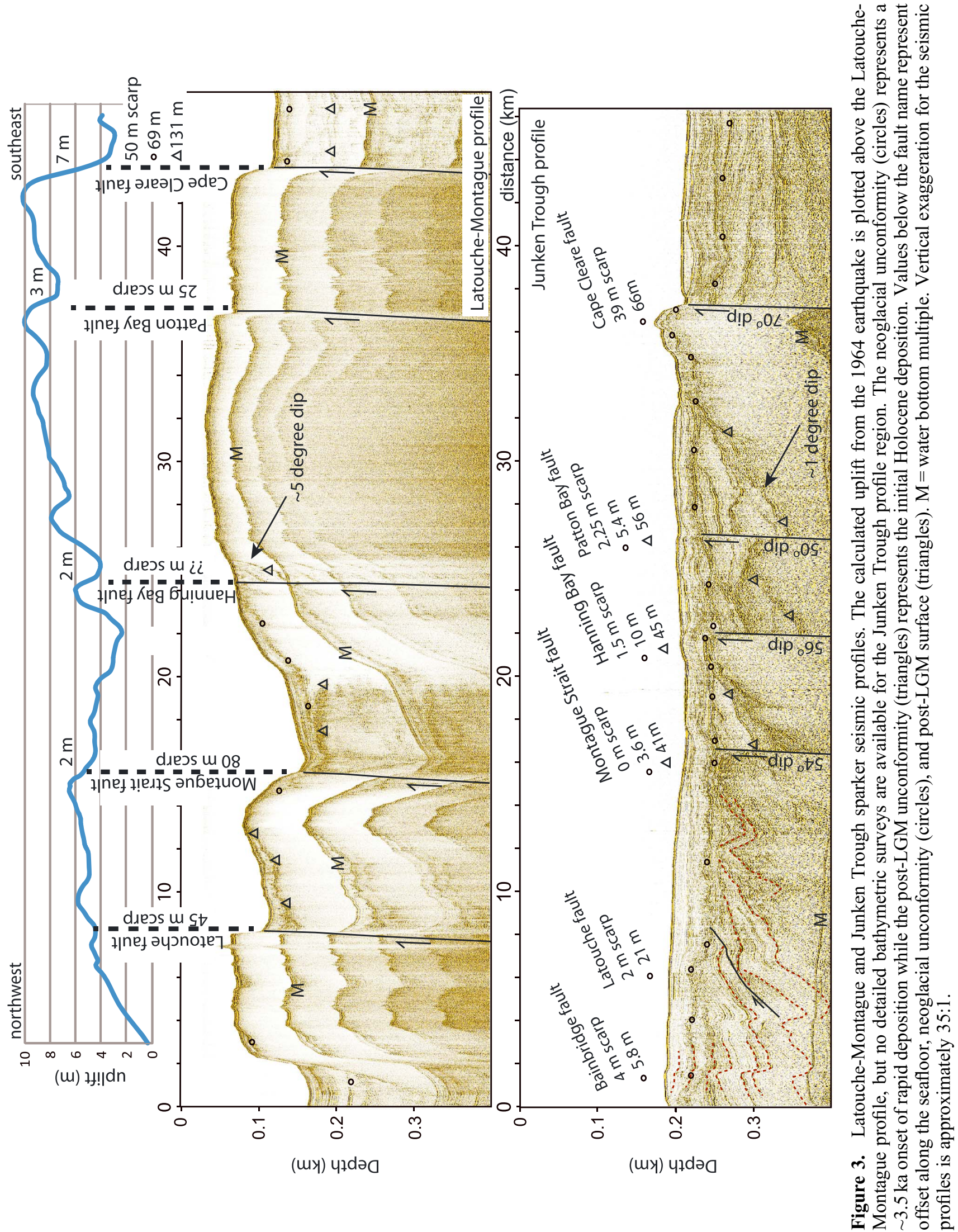
$5 \mathrm{~m}$ documented around Hanning Bay on Montague Island and $3.5 \mathrm{~m}$ on Middleton Island (Figures 1 and 2). Plafker [1969] identified the offshore extension of the Patton Bay fault as the source of a local tsunami that inundated southern Alaska shorelines, but found no evidence that the Hanning Bay fault extended offshore. Splay faults that extend across the western Gulf of Alaska shelf are consistent with the Plafker [1969] observations and the Suleimani et al. [2011] tsunami model, which showed that a source on the continental shelf is needed to produce the tsunami that arrived at Seward about $30 \mathrm{~min}$ after the earthquake. Plafker [1969] recognized that faults must have ruptured in the Gulf of Alaska during the 1964 earthquake to produce the footwall uplift along the south shore of Montague Island and to account for additional tsunami runups along the Kenai Peninsula; however, these hypothesized faults or fault extensions have not been identified.

[7] Differencing of pre- and post-1964 bathymetric data reveals the subsea uplift patterns that complement the detailed measurements of shoreline uplift [Plafker, 1969]. The baseline for our bathymetric differencing analysis is a relatively dense 1927-1928 survey carried out near Montague Island and north to Bainbridge Passage (Figure 2). This data set consists of approximately 8700 measured points that were depth calibrated by up and down lead line casts [Malloy, 1964]. The horizontal positions were controlled by measuring angles between prominent features on adjacent islands, and depth errors were minimal due to the lead line method. We gridded the data at $0.2 \mathrm{~km}$ spacing using a linear interpolator, and then we differenced these gridded data with points acquired during three post-1964 bathymetric surveys (one sounding survey and two multibeam surveys). We removed grid cells that did not contain repeat measurements, removed measurements from steep slope areas, and then regridded the uplift data to a $0.5 \mathrm{~km}$ grid. The removal of points from steep slopes addressed the poor spatial controls provided with the two data sets. To confirm the validity of our analysis, we compare profile data along densely sampled west-east bathymetric transects to adjacent shoreline uplift measurements derived from the upper growth limit of barnacles [Plafker, 1969]. Although large survey errors may be expected, the two sets of measurements show vertically consistent results along the shoreline to within less than $1 \mathrm{~m}$ (Figure 2).

[8] The 1964 earthquake caused as much as $15 \mathrm{~m}$ of total vertical uplift mostly along two arcuate water bottom lineations (scarps) that extend southwest from Montague Island on what we term the Cape Cleare bank (Figure 2). A maximum $12 \mathrm{~m}$ vertical uplift across an offshore portion of the Patton Bay fault is recorded (near cross section C-C' in Figure 2). We document a second large vertical uplift along a subparallel seaward lineament (near cross section D-D'). Although Plafker [1969] identified a fault near Cape Cleare on Montague Island that appears to connect with this seaward lineation, he found no evidence on land that this "Cape Cleare fault" ruptured during the 1964 earthquake. Our results show broad asymmetric hanging wall uplift on both the Patton Bay and Cape Cleare faults with a gentle decrease in hanging wall uplift away from each fault (Figure 2).

[9] Our differencing analysis, coupled with Plafker's [1969] shoreline uplift measurements, point to other seafloor ruptures related to the 1964 earthquake. The residual 2-3 m uplift outboard and offshore of the Cape Cleare fault (Figure 2) is consistent with additional up dip megathrust splay faults in the Gulf of Alaska identified by Fruehn et al. [1999], and a nearly $5 \mathrm{~m}$ residual uplift on the southeastern shore of Montague Island is consistent with one or more additional splay faults located below the eastern Gulf of Alaska shelf (Figure 1) [Plafker and Rubin, 1978; Finn, 2012].

[10] Although more modest than the Patton Bay and Cape Cleare faults, uplift identified by our differencing analysis northwest of the Patton Bay fault is coincident with subparallel bathymetric lineations west of Montague, Latouche, and Bainbridge Islands (Figure 2). We calculate a bulk seafloor elevation change from the 1964 earthquake of 2 to $11 \mathrm{~m}$ between the Alaska mainland and the Patton Bay fault, with focused uplift along water bottom lineations that record vertical displacements of as much as $2 \mathrm{~m}$ (Figure 3). The average bulk uplift of $4 \mathrm{~m}$ recorded northwest of the Cape Cleare Bank is similar to the average uplift of 2-4 m recorded on the adjacent Bainbridge and Latouche Islands but likely greater than the uplift offshore of Kenai Peninsula (Figure 2) [e.g., Johnson et al., 1996]. The northernmost lineation that we document to contain a measureable component of 1964 motion, beneath Bainbridge Passage (Figure 2), appears adjacent to the maximum recorded horizontal displacement from the 1964 earthquake [Plafker, 1969]. These faults that ruptured during the 1964 earthquake coincide with $>100 \mathrm{~km}$-long lineaments that extend to the northeast beneath PWS and to the southwest beneath the Gulf of Alaska.

\section{Interpretation}

\subsection{Holocene Faulting From Seismic Results}

[11] To characterize long-term motion along active faults, we present three sparker seismic profiles that document the postglacial deposition and uplift history. Our sparker seismic records contain usable signals to $2 \mathrm{kHz}$ that provide submeter vertical resolution of strata. Because global sea level was approximately $120 \mathrm{~m}$ below modern sea level during the last glacial maximum (LGM) when glaciers occupied areas of PWS [e.g., Hamilton, 1994; Peltier and Fairbanks, 2006], we assume that shallow waterways were strongly influenced by glacial erosion and that bathymetric lineations at greater than $120 \mathrm{~m}$ below sea level are the result of postglacial faulting. Based on proximal regional records indicating deglaciation around 14 kya [Reger, 1991], we suggest that deglaciation on the adjacent continental shelf may have been $\sim 15$ kya. Other authors speculate that deglaciation on the shelf occurred closer to 10 kya [e.g., Sheaf et al., 2003], but no direct measurements for this timing are currently available. Based on the related sediment unconformity, modern sedimentation rates recorded within the near-shore Gulf of Alaska environment are estimated at $\sim 10 \mathrm{~mm} / \mathrm{yr}$ [Carlson and Molnia, 1975], and are consistent with both an ice-proximal marine sediment source and sediments derived from the Copper River delta [Carlson and Molnia, 1975; Davies et al., 2011]. As with previously published seismic surveys in the region [e.g., Carlson and Molnia, 1975, Carlson, 1989], we observe an unconformity within the upper $150 \mathrm{~m}$ below seafloor that defines the onset of postglacial deposition. We subsequently refer to this horizon as the "post-LGM unconformity" and assume a conservative age of $15 \mathrm{kya}$. We 
then use our sparker results to identify fault locations and then use reflector offsets to estimate earthquake ruptures in the vicinity of the greatest displacement observed during the 1964 earthquake.

[12] The $47 \mathrm{~km}$-long Latouche-Montague seismic profile extends from near the mouth of Bainbridge Passage south across prominent up-to-the-north scarps that define active faults (Figure 2). An undulating seafloor topography and lack of subbottom reflectivity suggests that little postglacial sediment has been deposited along much of this profile (Figure 3). Little sediment accumulation is consistent with Tertiary bedrock samples that were obtained on the Cape Cleare Bank seafloor [e.g., Evans et al., 2000]. However, we identify subbottom reflectivity on the profile beneath deep water channels that is consistent with Holocene deposition on the footwall of the identified faults. Although repeat bathymetric survey points were not acquired along the orientation of the Latouche-Montague seismic profile, we present a cross section of the gridded differencing values to compare to our seismic results (Figure 3 ).

[13] The $46 \mathrm{~km}$-long Junken Trough seismic profile parallels the Latouche-Montague profile but is located in an area where sparse bathymetric data prevent detailed mapping of water bottom lineations (Figure 2). The profile, acquired along a glacially scoured channel, is located outside the limits of the subducted Yakutat terrane (Figure 1). The water depth suggests the Junken Trough remained below sea level during the LGM and likely represents one of the initial icefree channels that transported sediment away from the southern Alaska margin. With the exception of one bathymetric ridge that appears along the southern limit of the profile, we identify subbottom reflectivity in the upper $150 \mathrm{~m}$ to be late Pleistocene and Holocene strata (Figure 3). We identify a prominent unconformity that we interpret to be a neoglacial hiatus in sedimentation estimated at $3.5 \mathrm{kA}$ that appears at approximately $30 \mathrm{~m}$ below the seafloor [e.g., Barclay et al., 2009]. We interpret the onset of post-LGM deposition at the base of a seismically transparent zone that likely represents initial postglacial coarse-grained sediment deposition. Although water bottom scarp heights can provide slip rate estimates, erosion and relatively rapid deposition rates can lead to large uncertainties in these estimates. Here we utilize vertical displacement across the neoglacial and post-LGM unconformity to provide more accurate Holocene slip rate estimates for identified faults.

\subsection{Cape Cleare Fault}

[14] There is no evidence for motion on the Cape Cleare fault on Montague Island during the 1964 earthquake [Plafker, 1969]. However, we measure a $50 \mathrm{~m}$ scarp across the Cape Cleare fault near the $43 \mathrm{~km}$ position of the Latouche-Montague seismic profile, at a location that is coincident with $7 \mathrm{~m}$ of bathymetric uplift during the 1964 earthquake (Figure 3). Additionally, water bottom samples compiled by Evans et al. [2000] point to bedrock on the seafloor surface of the hanging wall block of this fault whereas Holocene sediments derived primarily from a Copper River source were deposited on the footwall block [e.g., Royer et al., 1990]. Our sparker seismic profile shows truncated reflectors and two unconformities at 18 and $80 \mathrm{~m}$ below the seafloor in the footwall block. Although we cannot state with certainty that these unconformities represent neoglacial and post-LGM age boundaries, the measured
Holocene sediment thickness is consistent with other areas within the Gulf of Alaska shelf [Carlson and Molnia, 1975]. Vertical offset from the hanging wall surface to the interpreted LGM unconformity on the footwall block measures $131 \mathrm{~m}$. If the $7 \mathrm{~m} 1964$ earthquake uplift measured along this profile is an average uplift per megathrust earthquake, we estimate that 19 Holocene earthquakes on this fault are needed to account for the total postglacial fault offset. Assuming the post-LGM sedimentation represents a 15 kya marker and that this fault ruptured with each megathrust earthquake, we estimate a vertical slip rate of $9 \mathrm{~mm} / \mathrm{yr}$ and a recurrence interval for large subduction zone earthquakes of 789 years. This recurrence interval is remarkably consistent with other paleoseismic and seismological studies in the region (see summary in Carver and Plafker [2008]), which implies that this megathrust splay fault ruptured during most Holocene great earthquakes in this region. Our estimates assume no seafloor erosion and a flat topography immediately following the last glaciation, and there is an uncertain age estimate on the post-LGM onset of deposition. Regardless of these uncertainties, our data provide evidence that the Cape Cleare fault is the active splay fault with the greatest uplift along this profile during the Holocene, and thus may pose the greatest hazard of all identified faults beneath the western Gulf of Alaska shelf.

[15] On the Junken Trough seismic profile, a $39 \mathrm{~m}$ bedrock high appears at the $36 \mathrm{~km}$ position, which is along strike of the Cape Cleare fault (Figure 3). Although we observe subbottom reflectivity to depths greater than $200 \mathrm{~m}$ below the seafloor, we cannot clearly identify the post-LGM reflector. We measure a $66 \mathrm{~m}$ offset of the neoglacial reflector compared to a $69 \mathrm{~m}$ offset along the Latouche-Montague profile, but due to the lack of postglacial sediment deposition on the hanging wall side of the fault, we infer that the total neoglacial offset does not accurately represent tectonic slip. However, the decrease in offset of both the seafloor scarp and the neoglacial unconformity suggests that the Cape Cleare fault has experienced a decrease in late Holocene uplift along the Junken Trough seismic profile compared to uplift on the Cape Cleare Bank.

[16] Based on truncated reflectors, we measure a $70^{\circ}$ dip on the Cape Cleare fault on the Junken Trough profile (Figure 3). This reverse fault, along with north-dipping strata in the hanging wall, is consistent with a $>60 \mathrm{~km}$ long, northwest-dipping splay fault. Assuming prior earthquakes produced an uplift pattern similar to the 1964 earthquake, structural dip in the hanging wall should and does increase with increasing depth. Our results suggest that the Cape Cleare fault has shown a repeated pattern of rupture for many earthquake cycles. Given the flat to gentle seaward dip of footwall reflectors on both profiles and a lack of parallel seafloor lineaments to the south, we suggest that megathrust splays immediately seaward of the Cape Cleare fault are either not present or have only minor postglacial displacement. The residual uplift of the shoreline on Montague Island south of the Cape Cleare fault thus appears to be caused by splay faults that reach the seafloor well to the south of the Cape Cleare fault, close to continental slope [e.g., Fruehn et al., 1999].

\subsection{Patton Bay Fault}

[17] The primary surface rupture related to the 1964 earthquake was the Patton Bay fault, which was identified on 
Montague Island as an en echelon, $45 \mathrm{~km}$ long, $50^{\circ}-70^{\circ}$ northdipping reverse fault [Plafker, 1969]. Integrating onshore mapping results with offshore bathymetry results, we observe the greatest uplift for the 1964 rupture of the Patton Bay fault immediately southwest of Montague Island on the Cape Cleare Bank and $8 \mathrm{~km}$ north of the greatest 1964 uplift documented on the Cape Cleare fault (Figure 2). The bathymetry shows a $40 \mathrm{~m}$-high marine terrace that decreases in height to the southwest. We document $12 \mathrm{~m}$ of offset related to the 1964 earthquake where the scarp measures $35 \mathrm{~m}$ tall, and a decreasing scarp height to the southwest. Due to the location and shallow water environment where the Patton Bay fault is crossed by the Latouche-Montague seismic profile (position $36 \mathrm{~km}$ ), we observe little Holocene sediment on the footwall side of the fault. We infer tectonic block rotation caused reflectors to tilt $5^{\circ}$ to the north at position $25 \mathrm{~km}$ (Figure 3 ). The $40 \mathrm{~m}$ maximum offshore scarp height provides a minimum estimate of Holocene uplift and is a correct measure of the total uplift if erosion rates are similar on both the footwall and hanging wall.

[18] The inferred Patton Bay fault is at position $26 \mathrm{~km}$ along the Junken Trough seismic profile. At this location, we infer a water bottom offset of $2.25 \mathrm{~m}$, and we estimate $5.4 \mathrm{~m}$ and $56 \mathrm{~m}$ offsets across neoglacial and LGM unconformities, respectively (Figure 3). Utilizing the two unconformities, we estimate a slip rate of $1.5 \mathrm{~mm} / \mathrm{yr}$ and $3.7 \mathrm{~mm} / \mathrm{yr}$ or an average displacement of 1-2 $\mathrm{m}$ per earthquake. North dipping reflectors to more than $50 \mathrm{~m}$ below the seafloor at the Patton Bay fault show clear lateral truncations. Whereas the Patton Bay fault is recognized as the most active fault both on and immediately offshore Montague Island, a smaller relative uplift on the Junken Trough seismic profile suggests that the Patton Bay fault poses a smaller tsunami and seismic hazard to the southern Kenai Peninsula than does the Cape Cleare fault. Utilizing truncated reflectors imaged on the Junken Trough seismic profile, we measure a $50^{\circ}$ north dip on the Patton Bay reverse fault with north-dipping strata (upward of $1^{\circ}$ ) in the hanging wall and footwall blocks. The increasing dip with depth below the neoglacial unconformity in the hanging wall of the Patton Bay fault is consistent with coseismic tilt, similar to our observations for the Cape Cleare fault.

[19] The $50^{\circ}$ dip of the Patton Bay fault is less than our estimate for the Cape Cleare fault but is consistent with Plafker's [1969] dip measurements on Montague Island. We characterize the Patton Bay fault as a $>75 \mathrm{~km}$-long megathrust splay fault with displacements as great as $12 \mathrm{~m}$ on the Cape Cleare Bank during the 1964 earthquake. However, using offsets on the LGM reflector along the Junken Trough profile, we calculate more modest Holocene displacements to the west of the Cape Cleare Bank.

\subsection{Hanning Bay Fault}

[20] The Hanning Bay fault is mapped along the northwest shore of Montague Island where Plafker [1969] documented upward of $5 \mathrm{~m}$ uplift along a $\sim 10 \mathrm{~km}$-long surface rupture (Figure 2). Bathymetric lineations parallel to the southern margin of Montague Strait extend into the Gulf of Alaska, and although Plafker [1969] did not extend the Hanning Bay fault to the southwest, we propose that this fault extends offshore along this identified lineament and that this fault is a major regional splay fault. Although we observe a lack of subbottom reflectivity and only modest seafloor displacements along the Latouche-Montague seismic profile (Figure 3), we identify truncated reflectors approximately $12 \mathrm{~km}$ offshore of the mapped portion of the Hanning Bay fault. Although we cannot directly tie the interpreted Hanning Bay fault to the named fault on Montague Island because no prominent seafloor terrace is present (possibly the result of active erosion), the distance of this fault from the Patton Bay fault on the LatoucheMontague seismic profile is consistent with the $10 \mathrm{~km}$ distance between the two faults mapped on Montague Island (Figure 2).

[21] We identify the Hanning Bay fault on the Junken Trough seismic profile at position $22 \mathrm{~km}$ where there is clear evidence for a $56^{\circ}$ north-dipping reverse fault (Figure 3). Here a $1.5 \mathrm{~m}$ water bottom scarp coincides with $10 \mathrm{~m}$ offset on the neoglacial unconformity and $45 \mathrm{~m}$ offset of post-LGM strata or an average slip rate of approximately $3 \mathrm{~mm} / \mathrm{yr}$. Assuming the identified scarp on the Latouche-Montague seismic profile and reverse fault on the Junken Trough seismic profile are the Hanning Bay fault, we interpret the Hanning Bay fault as a $>60 \mathrm{~km}-\mathrm{long}$ fault. As with the Patton Bay and Cape Cleare faults, northward dips on hanging wall reflectors are consistent with repeated tilting in surface rupturing earthquakes. Using uplifted shoreline and seafloor measurements from the 1964 earthquake, and reflector dip on the hanging wall portion of the Hanning Bay fault to estimate Holocene uplift rates, the greatest displacement for the Hanning Bay fault is likely on Montague Island. The average displacement per earthquake is approximately $2 \mathrm{~m}$ beneath the Junken Trough, greater than the displacements measured across the Patton Bay fault.

\subsection{Montague Strait Fault}

[22] To the north of the Hanning Bay fault, we identify additional reverse faults that show motion during the 1964 earthquake (Figure 3). Along the northern channel of Montague Strait near Latouche Island, we define the Montague Strait fault from a $110 \mathrm{~m}$ north side up scarp (Figure 2) [Finn, 2012]. Across the Latouche-Montague seismic profile, the tectonic history of the $80 \mathrm{~m}$ scarp at position $15 \mathrm{~km}$ is difficult to independently assess (Figure 3). A thin drape of Holocene sediment thickens toward the channel center and has a total post-LGM unconformity offset at the scarp of $105 \mathrm{~m}$. The rounded nature of the channel margin suggests that erosion has modified the scarp that extends laterally (along a series of left-stepping segments) more than $100 \mathrm{~km}$ (Figures 1 and 2). A scarp height of more than 3 times the Patton Bay fault suggests that the bathymetric scarp at the northern margin of Montague Strait (1) is enhanced during past glaciations, (2) includes a pre-Holocene slip history, and/or (3) is the dominant tectonic player for the PWS area. From our 1964 differencing analysis and uplifted shoreline measurements of less than $4 \mathrm{~m}$ [Plafker, 1969], we interpret this presumed fault as active, but with Holocene displacements less than the Hanning Bay, Patton Bay, and Cape Cleare faults. Given that the base of the channel was not exposed during the LGM and that the channel represents the major outlet of Quaternary sediment transport from PWS to the Gulf of Alaska, we suggest this scarp may have survived multiple glacial cycles and has been enhanced by active submarine erosion. Long-term exhumation rates from apatite-helium closure data suggest that Knight and Latouche Islands are being uplifted at approximately one third of the rate of Montague Island [Arkle et al., 2013], consistent with our analysis and with shoreline uplift measurements from the 1964 earthquake [Plafker, 1969]. 

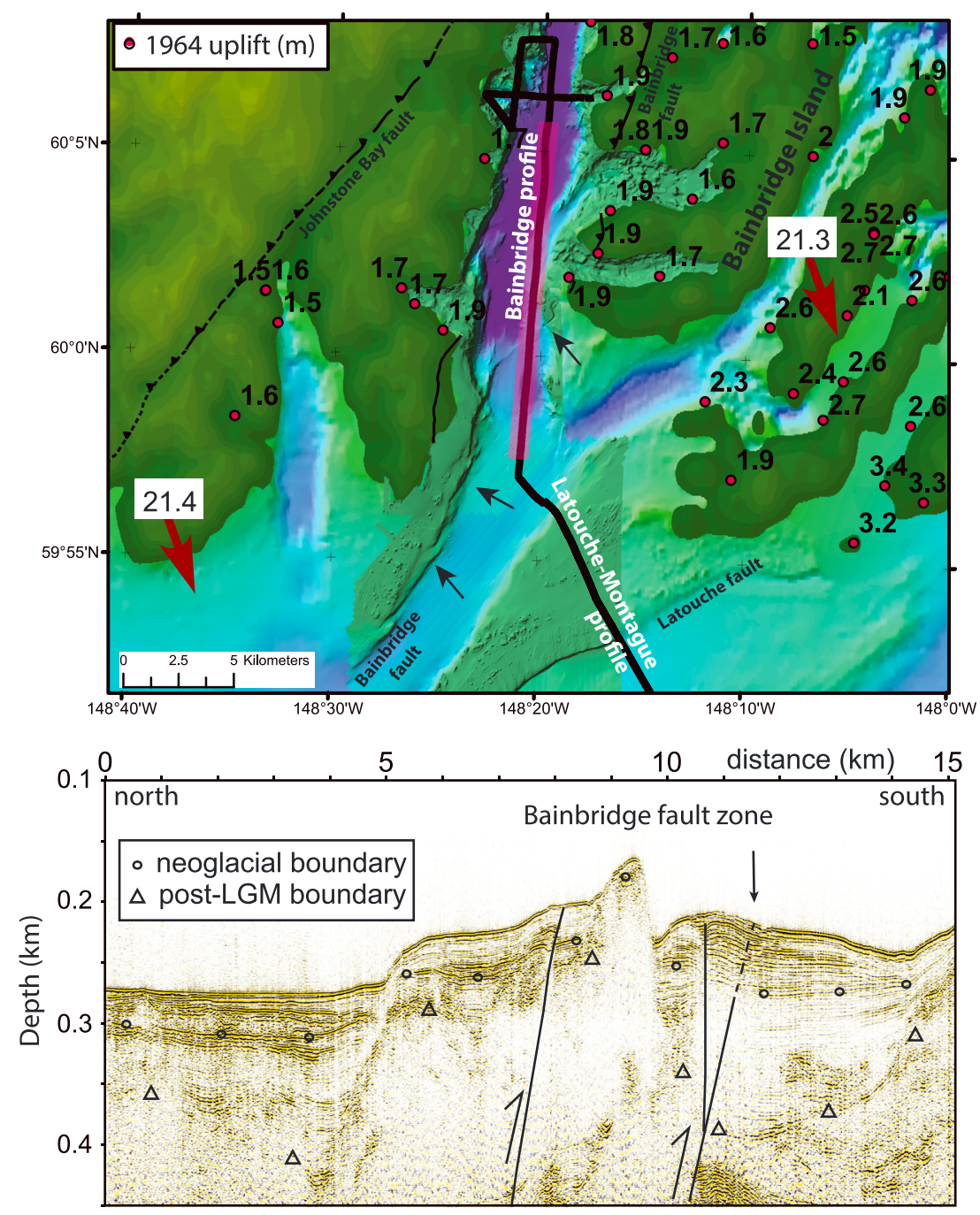

Figure 4. (top) Bathymetric map for the Bainbridge Passage area with the location of sparker seismic profile. The Bainbridge and Johnstone Bay faults are affiliated with the Contact fault system. The Bainbridge fault crosses Bainbridge Passage and extends into the Gulf of Alaska as a left-stepping lineation. Shoreline measurements from the 1964 earthquake show a differential uplift of $0.2 \mathrm{~m}$ across the Bainbridge fault and a reduction of $0.1 \mathrm{~m}$ horizontal displacement. (bottom) Sparker seismic profile showing Holocene and older strata offset across the Bainbridge fault zone. Tilted and offset reflectors represent strands of the Bainbridge fault zone. The neoglacial unconformity (circles) represents a $\sim 3.5 \mathrm{ka}$ onset of rapid deposition while the post-LGM unconformity (triangles) represents the initial Holocene deposition. Vertical exaggeration for the seismic profile is approximately 20:1.

[23] The greatest water depth along both the LatoucheMontague and Junken Trough seismic profiles correlates with the offshore extension of Montague Strait (Figure 2). Although the slip history and dip of the Montague Strait fault is unclear from the Latouche-Montague profile alone, the Junken Trough seismic profile clearly shows a north-dipping reverse fault at position $16 \mathrm{~km}$ that separates tilted footwall strata from folded hanging wall strata (Figure 3 ). This $54^{\circ}$ north-dipping fault corresponds to a negligible seafloor scarp, but we document a $3.6 \mathrm{~m}$ displacement on the upper unconformity and $41 \mathrm{~m}$ offset and truncation of the slightly $\left(\sim 1^{\circ}\right)$ north-dipping LGM boundary. The displacement of post-LGM strata is slightly less than measured offsets of the Patton Bay and Hanning Bay faults on this profile, with an estimated slip rate between 1 and $3 \mathrm{~mm} / \mathrm{yr}$. Assuming these displacements are solely related to tectonic uplift, the lack of measurable seafloor offset along this profile and minor offset across the neoglacial unconformity suggests that little slip has occurred during the last few earthquake cycles. We interpret the Montague Strait fault as a major tectonic feature that separates a zone of splay faulting to the south from a zone of regional folding to the north. Although long-term geochronology exhumation rates and modest uplift during the 1964 earthquake suggest the Montague Strait fault is a relatively low hazard fault when compared to the other splay faults near PWS, this fault may extend $>100 \mathrm{~km}$ across PWS and into the Gulf of Alaska and have comparable Holocene uplift to the Patton Bay fault. It should therefore warrant the status of a high hazard fault.

\subsection{Latouche Fault}

[24] The northern portion of the Latouche-Montague Strait seismic profile crosses a $45 \mathrm{~m}$-high scarp at the $8 \mathrm{~km}$ position that, like the Patton Bay and Cape Cleare faults, forms a 


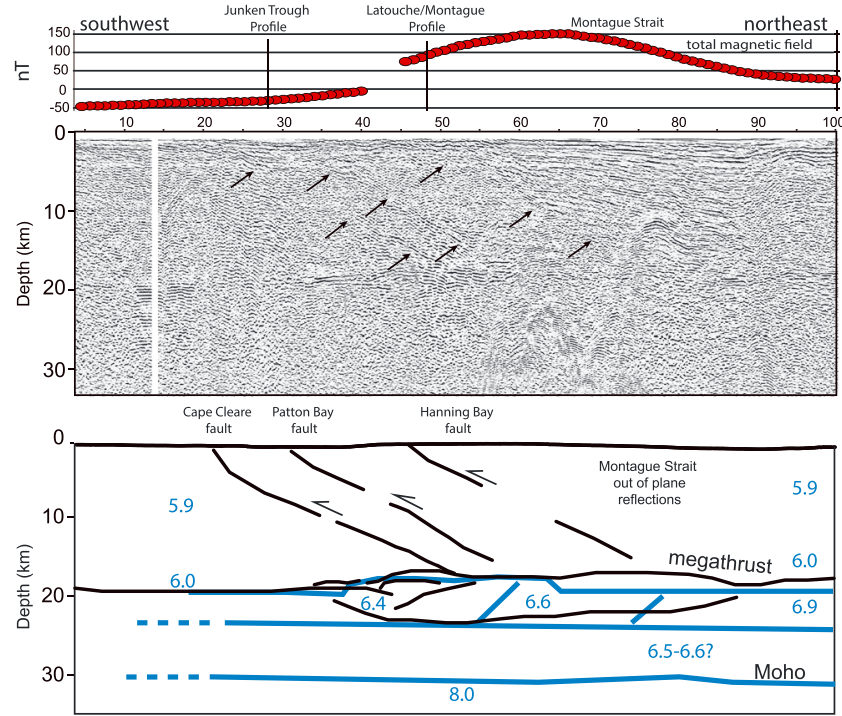

Figure 5. (top) Total magnetic field along the TACT PWS seismic profile, (middle) TACT PWS seismic reflection profile with arrows showing splay fault reflectors, and (bottom) seismic interpretation from the TACT PWS profile (black lines) and from the Brocher et al. [1994] refraction results (blue lines and labels). Note that the reflector at $\sim 20 \mathrm{~km}$ depth matches the change in refraction velocity from 6.0 to $6.9 \mathrm{~km} / \mathrm{s}$ and that the reflections below this depth are poorly imaged. Vertical exaggeration for the seismic profile is approximately $1: 1$.

steep-sided, shallow-water scarp with bedrock seismic signature on the seafloor to the north of the scarp and $47 \mathrm{~m}$ of Holocene sediment below the seafloor to the south of the scarp (Figures 2 and 3). Although the bathymetry differencing indicates this scarp experienced little to no uplift during the 1964 earthquake (Figure 2), the $92 \mathrm{~m}$ displacement of the top of Tertiary (?) rocks (post-LGM surface) across this lineament and the sizable length of the lineation, which may merge with the Montague Strait fault to the northeast, suggests that the scarp is the expression of an active fault that we term the Latouche fault (Figure 3). The minor role of this fault during the last megathrust earthquake suggests either that the 1964 earthquake was not representative of the longterm uplift history of this fault, that the scarp is enhanced by erosion, or that the fault scarp has survived multiple glacial cycles as discussed for the Montague Strait fault.

[25] Along the Junken Trough seismic profile northwest of the Montague Strait fault, our seismic image indicates deformation changes from kilometer-scale tilting and high-angle faulting to folding and low-angle faulting near mainland Alaska (Figure 3). A low-angle thrust fault $\left(\sim 1^{\circ}\right.$ dip) with a clear fault plane reflection appears approximately $8 \mathrm{~km}$ northwest of the Montague Strait fault, in a position that corresponds to the Latouche fault. Here the seafloor shows a $2 \mathrm{~m}$ scarp, and there is a $21 \mathrm{~m}$ offset of the neoglacial unconformity. Due to the paucity of bathymetry data and lack of reflectivity in the hanging wall along the Latouche-Montague seismic profile, it is unclear how or whether this low-angle fault transitions to an apparent high-angle fault as identified on the Latouche-Montague profile. However, we interpret the Latouche fault as active, as possibly merging with the
Montague Strait fault near Latouche Island, and perhaps capable of generating a tsunami that could cause damage along the Alaska coastline.

\subsection{Bainbridge Fault and Contact Fault System}

[26] Near the northwestern end of the Junken Trough seismic profile at position $2 \mathrm{~km}$, a $4 \mathrm{~m}$ water bottom scarp corresponds with a fold that appears to grow uniformly with depth (Figure 3). Although detailed bathymetry is not available within the Junken Trough, a 2004 multibeam survey that focused on the entrance to Bainbridge Passage shows a prominent, up-to-the-north, northeast-trending seafloor scarp near the northern limits of the Junken Trough profile (Figure 4). We interpret this growth fold to represent the along-strike expression of the Bainbridge fault, a fault that parallels and is possibly related to the Contact fault system (Figure 1) [Helwig and Emmet, 1981; Dumoulin, 1987; Bol and Gibbons, 1992; Wilson and Hults, 2012]. Along the Junken Trough profile, this fold is likely rooted in a fault at depth, and a large seafloor scarp suggests this fault may pose a significant tsunami or ground-shaking hazard to adjacent mainland communities and infrastructure, including Seward and other shallow waterways along the southern Kenai Peninsula [e.g., Plafker, 1969; Suleimani et al., 2011].

[27] To further characterize the Bainbridge fault, we present the $20 \mathrm{~km}$-long Bainbridge Passage seismic profile (Figure 4). This seismic profile documents more than $100 \mathrm{~m}$ of predominantly Holocene sediment overlying the post-LGM unconformity beneath Bainbridge Passage, which has been fed by the Bainbridge glacier and small rivers. The highly reflective seismic character that dominates the upper $50 \mathrm{~m}$ below the seafloor suggests that alternating coarse- and fine-grained proximal sources dominate postglacial deposition over time periods of centuries, while a more transparent zone below the upper seismic unit likely represents rapid, coarse-grained deposition following early Holocene glacial retreat [e.g., Cowan et al., 2010]. The seismic profile approaches land near a prominent bedrock knob that extends offshore from Bainbridge Island. Adjacent to the knob is a seafloor lineament with a $0.5 \mathrm{~m}$ vertical offset (arrow in Figure 4) and a local seafloor high evident in the bathymetric differencing and in nearby shoreline measurements (Figures 2 and 4) [Plafker, 1969]. Folded strata and offset reflectors on the seismic profile near the lineament indicate that the Bainbridge fault is active and offsets Holocene strata. The Plafker [1969] shoreline measurements record a difference of $0.2 \mathrm{~m}$ across the Bainbridge fault during the 1964 earthquake, but our bathymetric differencing results suggest more than $1 \mathrm{~m}$ of north-sideup uplift below the seafloor (Figure 2). This discrepancy may be best explained by bathymetric measurement errors but could also be explained by a greater uplift beneath Bainbridge Passage. Evidence for growth faulting within the shallow seismic strata suggests repeated Holocene motion. Given that the shoreline along Bainbridge Passage is the location of maximum horizontal displacement during the 1964 earthquake and that no surface faulting was identified on land immediately following the earthquake [Plafker, 1969], we interpret the Bainbridge fault to represent the northernmost thrust fault related to the 1964 earthquake.

[28] The Contact fault system, of which the Bainbridge fault is a component, is comprised of faults that parallel the 


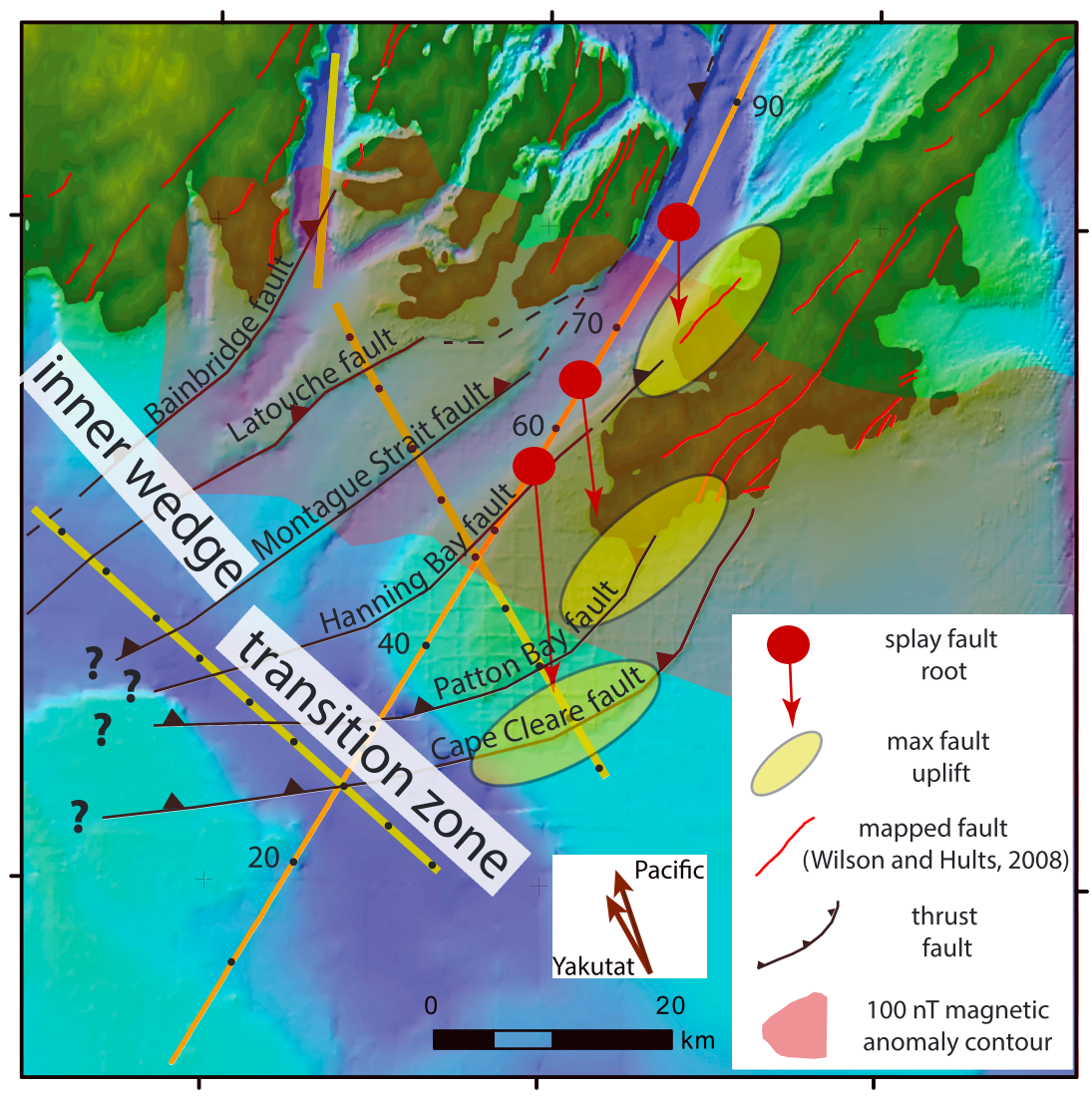

Figure 6. Bathymetric and topographic map of the Cape Cleare/Montague Island area showing the splay fault locations on the seafloor (Figure 3), land surface [Plafker, 1969], and on the megathrust (Figure 4). Note the north-south alignment of maximum fault uplifts at the outer limit of inner wedge deformation (as defined by Wang and $H u$ [2006]) and the trailing edge of the subducted Yakutat terrane [from Griscom and Sauer, 1990].

Alaska coastline west to Kodiak Island and east beneath PWS [e.g., Nelson et al., 1985; Dumoulin, 1987; Wilson and Hults, 2012]. The fault system roughly parallels the transition from uplift to subsidence during the 1964 earthquake (Figure 1) [e.g., Plafker et al., 1994]. However, the fault system was initially defined by Helwig and Emmet [1981] as a terrane boundary separating older flysch-dominated deep water rocks on the northwest side from younger metasedimentary Prince William terrane rocks on the southeast side. East of PWS, the Contact fault is defined by a series of mostly dextral strike-slip faults that may have formed during initial Eocene accretion. In contrast, the Contact fault system within western PWS is composed of subparallel thrust faults that are accommodating postaccretion deformation [e.g., Dumoulin, 1987; Bol and Gibbons, 1992; Plafker et al., 1994]. Fuis et al. [1991] showed north-dipping reflectors that project to the surface near the Contact fault system along the land-based TACT profile immediately north of PWS, and EberhartPhillips et al. [2006] showed that the Contact fault system can be characterized by a north-dipping low-velocity zone. The Bainbridge fault extends beneath western PWS along a northeast-trending bathymetric lineament that separates the deepest waters of PWS from adjacent islands, with a seafloor elevation change of nearly $1 \mathrm{~km}$. We suggest that this part of the Contact fault system is active, that it is a zone that accommodates internal deformation within the accretionary wedge [e.g., Bol and Gibbons, 1992] and that this fault system extends northeast beneath PWS and may connect with the fault system on Kodiak Island as mapped by Moore et al. [1983].

\section{Deep Splay Fault Geometry From Seismic Images}

[29] In 1988, over $1100 \mathrm{~km}$ of marine multichannel seismic data were acquired as part of the TACT program to examine the nature of the crust beneath accreted terranes north of the Aleutian trench (Figure 1). Brocher et al. [1994] published crustal refraction and wide-angle reflection results along transects that cross the PWS area. The PWS profile extends the length of Montague Strait southwest into the Gulf of Alaska, obliquely crossing the Hanning Bay fault, Patton Bay fault, Cape Cleare fault, and Junken Trough (Figure 1). Because islands are absent west of PWS, none of the six land-based receivers along the PWS profile were located southwest of the subducted Yakutat slab and refraction analyses were not carried out along the Gulf of Alaska portion of the profile. Brocher et al. [1994] identified a major crustal velocity change at about 16-24 km depth that correlates with the top of the Wadati-Benioff zone of seismicity and top of the subducted Yakutat block (Figure 5). They identified this layer as containing subducted Yakutat terrane rocks that thickens beneath the southwestern end of Montague Island. 
Southwest and below this high velocity/high magnetic susceptibility (gabbro?) layer, they interpret lower velocity, lower susceptibility rocks consistent with the Pacific plate rocks. Brocher et al. [1994] preferred a tectonic model with an imbricate set of thrust faults - related to megathrust splay faults - resulting in duplexing at the edge of the Yakutat terrane. This overthickened midcrustal layer where Yakutat rocks are presumably thrust over Pacific plate rocks corresponds to a prominent magnetic high that defines the subducted terrane boundary (Figure 1).

[30] We processed the PWS TACT multichannel seismic reflection data to identify and characterize splay faults that emerge from the megathrust (Figure 5). We used a standard processing approach that included prestack fk-filters to attenuate side swipe from Montague and Latouche Islands, a detailed velocity analysis, deconvolution, poststack migration, and depth conversion using the Brocher et al. [1994] velocity model. Integrating the reflection and refraction results, we interpret the décollement or megathrust on the TACT profile as a $\sim 1.5^{\circ}$ southwest-dipping reflector at $18-20 \mathrm{~km}$ depth beneath Montague Island. Brocher et al. [1994] interpreted this same boundary at $16 \mathrm{~km}$ depth beneath central PWS. Although we would expect to see a shallowing of the megathrust surface toward the trench, we attribute the increase in megathrust depth as due to the transition from Yakutat/ Pacific subduction beneath PWS to only Pacific plate subduction southwest of Montague Island. This gentle southwest dip of the top of the seismogenic zone has been estimated from relatively low-resolution tomography data [Eberhart-Phillips et al., 2006], but here we show with much higher resolution that the megathrust is indeed gradual and no large-scale midcrustal step is present at the Yakutat terrane boundary. This gradual transition contrasts with the Yakutat/Pacific plate boundary along the Transition fault beneath the eastern Gulf of Alaska, where an abrupt change in crustal thickness is observed [Christeson et al., 2010]

[31] Between positions $30 \mathrm{~km}$ and $90 \mathrm{~km}$ on the TACT profile, we observe additional reflectors below the megathrust that form a lens-shaped zone of reflective rocks (Figure 5). This region is coincident with the prominent magnetic high [Griscom and Sauer, 1990; Figure 1] and is consistent with a low seismic velocity $(6.4-6.6 \mathrm{~km} / \mathrm{s})$ zone beneath the megathrust in the Brocher et al. [1994] refraction model (Figure 5). We identify three megathrust splay faults emerging from the décollement surface along this $\sim 4 \mathrm{~km}$-thick, $60 \mathrm{~km}$-wide lens-shaped zone, all with apparent dips above the décollement of $\sim 20^{\circ}-30^{\circ}$. We observe a fault plane reflector that approaches the seafloor surface near the offshore extension of the Hanning Bay fault near position $45 \mathrm{~km}$ (Figures 5 and 6). This splay fault emerges from the megathrust at the northeast margin of the lens-shaped boundary that is coincident with an underlying $6.9 \mathrm{~km} / \mathrm{s}$ to a $6.6 \mathrm{~km} / \mathrm{s}$ velocity boundary. Our reflection results suggest a $\sim 1 \mathrm{~km}$ shallowing of the megathrust where the splay fault initiates. Although Plafker [1969] characterized the Hanning Bay fault as less important than the Patton Bay fault, the splay fault geometry allows for an independent rupture of the Hanning Bay fault.

[32] We identify a second listric splay fault that initiates at the décollement and surfaces at the position of the offshore position of the Patton Bay fault near the $30 \mathrm{~km}$ position of the profile (Figures 5 and 6). Although our reflection results do not show detailed topography along the top of the megathrust at the location of the base of the fault, Brocher et al. [1994] interpreted an abrupt $1.5 \mathrm{~km}$ step up to the southwest along the megathrust at this location. The fault plane reflector we identify confirms that the fault causing the largest measured uplift associated with the 1964 earthquake originated from the megathrust where a discrete step is present at the top of the subducting Yakutat slab. Finally, we identify a third fault plane reflector associated with a splay fault that emerges from the $20 \mathrm{~km}$ deep décollement approximately $10 \mathrm{~km}$ southwest of the Patton Bay splay fault (Figure 6). This reflector approaches the surface at the Cape Cleare fault near position $20 \mathrm{~km}$, where both reflection and refraction results show topography on the megathrust and a decrease in refraction velocity below the megathrust from $6.6 \mathrm{~km} / \mathrm{s}$ to $6.4 \mathrm{~km} / \mathrm{s}$. Our results confirm that the three parallel splay faults with the greatest Holocene displacements during the 1964 earthquake are independent splays originating from the top of the megathrust at relatively low angles. Because of the oblique orientation of the PWS TACT profile relative to other identified splay faults on the sparker seismic profiles, we cannot characterize the geometry of the thrust faults that surface north of Montague Strait. We conclude that the high magnetic suspectibility/high seismic velocity layer beneath the accretionary prism at the southwestern edge of the Yakutat terrane leads to splay fault generation. This observation suggests that topography, duplexing, and/or laterally changing lithologies along the megathrust have played a key role in the plate locking at the western limits of PWS [e.g., Zweck et al., 2002]. The significantly higher exhumation rates observed on Montague Island compared to areas farther north [Arkle et al., 2013] suggest that this boundary has remained in place for much of the Quaternary.

\section{Discussion}

\subsection{Subduction Zone Structural Domains and Asperity Focus}

[33] We identify active thrust faults related to subduction as far north as Bainbridge Passage, and other studies have found active splay faults south of PWS up to and beyond the continental slope break [e.g., Plafker, 1969; Fruehn et al., 1999; Finn, 2012]. We suggest that splay faults are present from the mainland coastline (Contact fault) to the trench in the PWS area. However, the documented uplift from the 1964 earthquake from both land and sea measurements, large offset scarps, and north-dipping hanging wall strata indicates that uplift was greatest along the south shore of Montague Island and Cape Cleare Bank. This region is coincident with the prominent magnetic anomaly (Figure 6) and is the location where splay faults diverge from the megathrust at the trailing edge of Yakutat slab subduction.

[34] Based on sparker seismic reflection results, we identify two regions with a contrasting deformation character (Figure 6). The Junken Trough seismic profile best shows this contrasting character where the region northwest of the Montague Strait fault shows broader folding and smaller slip rates on faults and folds when compared to the area southeast of the Montague Strait fault. Assuming this profile is located outside the area affected by Yakutat slab subduction, we presume this change in deformation style is only related to subducting slab geometry. Based on Coulomb wedge theory, Wang and Hu [2006] and Kimura et al. [2007] characterize 
the inner wedge of the accretionary prism as a region of weakly deformed internal structures. This deformational pattern is consistent with the region landward of the Montague Strait fault. This inner wedge remains weak during great earthquakes, splay faults are not common, and thus little permanent deformation is observed. However, we show that out-of sequence splay faults, or faults located well inboard from the deformation front, are still present and active. We identify the Bainbridge and Latouche faults as located within the inner wedge region. Although slip rates are lower for these faults compared to faults located farther offshore and these faults therefore may pose a lower tsunami hazard compared to the identified seaward faults, the proximity to onshore infrastructure suggests that the inner wedge faults still pose a seismic hazard for southern Alaska infrastructure.

[35] The region between the Montague Strait and Cape Cleare faults is characterized by tilted blocks that separate active, out-of-sequence megathrust splay faults that activate during most great earthquakes (Figure 6). Based on the near-surface tectonic expression, Wang and $H u$ [2006] and Kimura et al. [2008] would characterize this region as the transition zone of subduction between the inner and outer wedge zones that accommodates the bulk of subduction zone shortening. Although the transition zone is typically defined between the outer arc high and continental slope, we suggest that the shallow subduction angle from the buoyant Yakutat slab above the Pacific plate changes the subduction and splay fault geometry [e.g., Bruns, 1983; Brocher et al., 1994; Eberhart-Phillips et al., 2006; Fuis et al., 2008], pushes this transition zone closer to mainland Alaska for the PWS asperity, and provides the buoyancy to form the barrier islands of PWS. Assuming Montague Island defines a region of coseismic strengthening at the outer arc high and the trailing edge of the Yakutat terrane provides midcrustal heterogeneities and/or duplexing for splays to diverge from the megathrust, we outline an area with the maximum plate coupling where the faults will coseismically rupture during most great earthquakes (Figure 6). This area of high plate coupling lies adjacent to the poorly locked region to the west [Zweck et al., 2002] that hosts no outer arc islands and no major crustal boundary or laterally changing conditions along the megathrust that would foster splay fault formation (Figure 1).

[36] Assuming that the region of high plate coupling has remained fixed for many earthquake cycles, we would expect uplift rates to remain spatially consistent. Shoreline measurements show that uplift rates along northeast Montague Island were approximately one third of the uplift documented near Cape Cleare Bank following the 1964 earthquake. We show that 1964 uplift near the Junken Trough was likely similar to the uplift observed near the north end of Montague Island and that the uplift rate has remained relatively fixed through Holocene earthquake cycles. Using a $>10 \mathrm{Ma}$ time scale, apatite-fission track closure rates from Arkle et al. [2013] show a similar pattern where they suggest one third of the exhumation rate from rocks along northern Montague Island when compared to uplifts recorded near Cape Cleare. These studies suggest that southern Montague Island and Cape Cleare Bank have remained the focus of coseismic uplift during the Quaternary.

[37] In the vicinity of the Cape Cleare Bank, we observe northeast-striking faults that are responding to north-directed shortening (Figure 1). This oblique shortening results in left- stepping faults that transfer strain between adjacent splays. We observe the greatest uplift for the Hanning Bay fault on Montague Island; the greatest uplift for the Patton Bay fault along southern Montague Island and adjacent Cape Cleare Bank, and the greatest displacement for the Cape Cleare fault along the southern margin of the Cape Cleare Bank (Figure 6). We propose that this north-south alignment of the greatest coseismic uplift results from midcrustal heterogeneities that form a region of crustal duplexing at the southwest edge of the subducted Yakutat terrane. This region of greatest coseismic uplift is located at the transition zone between inner and outer wedge deformation.

\subsection{Along Strike Fault Character}

[38] The geometry and uplift of faults that extend across the western Gulf of Alaska shelf is unconstrained. However, it is consistent to link the Bainbridge and Contact faults with northeast-striking active faults near Kodiak Island [Fisher and von Huene, 1980; Moore et al., 1991; Fruehn et al., 1999; von Huene and Klaeschen, 1999]. On Kodiak Island, the Contact fault (and northernmost limit of 1964 coseismic uplift) is mapped along the island's south shore and active splay faults are mapped south of the island (Figure 1) [Fisher and von Huene, 1980]. Examining a seismic reflection profile located east of Kodiak Island, von Huene and Klaeschen [1999] showed that for the past $3 \mathrm{Ma}$, nearly all shortening has taken place within $30 \mathrm{~km}$ of the trench (transition zone and outer wedge). This places the region of maximum deformation outboard of Kodiak Island and coincident with the estimated region of 1964 maximum uplift (Figure 1) [Plafker, 1969]. We propose that the inner wedge region of active thrust faults, including the Bainbridge and Latouche faults, occupies much of the continental shelf west of PWS and that a series of subparallel splay faults likely link to faults that are mapped near Kodiak Island. This fault trend includes the mapped Contact fault both on mainland Alaska and Kodiak Island and is consistent with 1964 tsunami sources offshore of the Kenai Peninsula (Figure 1) [e.g., Plafker, 1969; Plafker and Savage, 2010; Suleimani et al., 2011].

[39] Because we identify splay faults as a series of subparallel faults near Montague Island, we suggest this pattern of subparallel splay faulting may extend across PWS to accommodate slightly oblique subduction. Thus, although strike-slip motion was proposed to accommodate tectonic shortening in some early tectonic models, we believe the majority of fault motion is dip-slip, as suggested by Cohen and Freymueller [2004]. We also suggest that many subparallel bathymetric lineations identified within PWS define active faults. Our observation that the Cape Cleare fault has experienced higher slip rates than the Patton Bay fault and that many parallel splay faults extend into the Gulf of Alaska revises earlier interpretations of a single Patton Bay fault extending from Montague to Kodiak Islands [Plafker, 1969; Zweck et al., 2002; Suito and Freymueller, 2009]. We prefer a zone of subparallel faults that connect Bainbridge Passage to Kodiak Island as the inner wedge portion of the subduction zone while splay faults emerge south of Kodiak Island, consistent with interpretations of Moore et al. [1991], Fruehn et al. [1999], and von Huene and Klaeschen [1999] for the Kodiak segment of subduction.

[40] We suggest that only moderate inner wedge deformation is expected below central PWS and beneath the near shore areas of the Kenai Peninsula, and that tsunamigenic 
splay faults below the western Gulf of Alaska shelf are located along strike of the Montague Strait fault and the Cape Cleare fault. This interpretation for the Kodiak subduction zone segment is consistent with subduction zone models for margin-perpendicular shortening, and places tsunami faults farther offshore from mainland Alaska than in the region adjacent to PWS. Although this interpretation is consistent with the data presented here, no high-resolution seismic or bathymetry data currently exist for the offshore Kenai Peninsula area that delineates specific tsunami generating fault strands.

\section{Conclusions}

[41] We observe multiple megathrust splay faults beneath western PWS and adjacent Gulf of Alaska. The maximum displacement on splay faults during the 1964 earthquake was upward of $12 \mathrm{~m}$ and long-term slip rates are as high as $9 \mathrm{~mm} / \mathrm{yr}$. The focus of Holocene uplift lies along the western edge of the subducted Yakutat slab, southwest of Montague and Latouche Islands. However, we identify active faults as far north as mainland Alaska (Bainbridge Passage) within the inner wedge of the accretionary prism.

[42] We identify left-stepping thrust faults beneath Bainbridge Passage, along the southeastern margin of Latouche and Knight Islands, and on Montague Island and the associated offshore Patton Bay and Cape Cleare faults. The abundance of left-stepping active faults that span the width of the Prince William terrane likely results from slightly oblique subduction and a strong influence of lateral heterogeneities along the subducted Yakutat terrane at the top of the seismogenic zone. Our new observations place constraints on local tsunami and earthquake sources and suggest laterally changing midcrustal lithologies play a strong role in splay fault formation. Although the greatest surface ruptures from Holocene earthquakes have been focused around Montague Island, splay faults that rupture the seafloor beneath PWS and the Gulf of Alaska, and faults on the Alaska mainland may be active during the next large earthquake.

[43] Splay faults related to megathrust earthquakes extend from the Bainbridge fault below the Alaska mainland south to the continental slope near the western limits of PWS. As subduction transitions from oblique shortening along the PWS segment to margin-perpendicular shortening along the Kodiak segment beneath the western Gulf of Alaska shelf, this en echelon pattern of faulting may be replaced with pure shortening along parallel thrust faults. Based on the lack of seismicity south of the Kenai Peninsula [Doser et al., 1999; Eberhart-Phillips et al., 2006] and the low degree of plate coupling [Zweck et al., 2002], we expect fewer splay faults between PWS and Kodiak Island.

[44] Acknowledgments. We would like to thank R/V Alaska Gyre Captain Greg Snedgen for his assistance in making the seismic acquisition cruise a success. Use of ProMAX seismic processing software was provided by Landmark Graphics Corporation Strategic University Alliance grant agreement 2013-UGP-009000. This work was funded from the U.S. Geological Survey National Earthquake Hazards Reduction Program award G11AP20143.

\section{References}

Arkle, J. C., P. A. Armstrong, P. J. Haeussler, M. G. Prior, S. Hartman, K. L. Sendziak, and J. A. Brush (2013), Focused exhumation in the syntaxis of the western Chugach Mountains and Prince William Sound, Alaska, Geol. Soc. Am. Bull., 125(5-6), 776-793, doi:10.1130/B30738.1.
Barclay, D. J., G. C. Wiles, and P. E. Calkin (2009), Holocene glacier fluctuations in Alaska, Quaternary Sci. Rev., 28, 2034-2048, doi:10.1016/j. quascirev.2009.01.016.

Bol, A. J., and H. Gibbons (1992), Tectonic implications of out-of-sequence faults in an accretionary prism, Prince William Sound, Alaska, Tectonics, 11(6), 1288-1300.

Brocher, T. M., G. S. Fuis, M. A. Fisher, G. Plafker, M. J. Moses, J. J. Taber, and N. I. Christensen (1994), Mapping the megathrust beneath the northern Gulf of Alaska using wide-angle seismic data, J. Geophys. Res., 99(B6), 11,663-11,685, doi:10.1029/94JB00111.

Bruns, T. R. (1983), Model for the origin of the Yakutat block, an accreting terrane in the northern Gulf of Alaska, Geology, 11, 718-721, doi:10.1130/ 0091-7613.

Carlson, P. R. (1989), Seismic reflection characteristics of glacial and glacimarine sediment in the Gulf of Alaska and adjacent fjords, Mar. Geol., 85(2), 391-416.

Carlson, P. R., and B. Molnia (1975). Preliminary isopach map of Holocene sediments, northern Gulf of Alaska, U.S. Geol. Surv. Open File Map 75-507, 1 sheet.

Carver, G., and G. Plafker (2008), Paleoseismicity and neotectonics of the Aleutian Subduction Zone-An overview, in Active Tectonics and Seismic Potential of Alaska, Geophys. Monogr. Ser. 179, edited by J. T. Freymueller et al., pp. 43-63, AGU, Washington, D. C., doi:10.1029/179GM03.

Christensen, D. H., and S. L. Beck (1994), The rupture process and tectonic implications of the great 1964 Prince William Sound earthquake, Pure Appl. Geophys., 142, 29-53.

Christeson, G. L., S. P. S. Gulick, H. J. A. van Avendonk, L. L. Worthington, R. S. Reece, and T. L. Pavlis (2010), The Yakutat terrane: Dramatic change in crustal thickness across the Transition fault, Alaska, Geology, 38(10), 895-898, doi:10.1130/G31170.1.

Cohen, S. C., and J. T. Freymueller (2004), Crustal deformation in the south central Alaska subduction zone, Adv. Geophys., 47, 1-63.

Cowan, E. A., K. C. Seramur, R. D. Powell, B. A. Willems, S. P. Gulick, and J. M. Jaeger (2010), Fjords as temporary sediment traps: History of glacial erosion and deposition in Muir Inlet, Glacier Bay National Park, southeastern Alaska, Geol. Soc. Am. Bull., 122(7-8), 1067-1080.

Davies, M. H., A. C. Mix, J. S. Stoner, J. A. Addison, J. Jaeger, B. Finney, and J. Wiest (2011), The deglacial transition on the southeastern Alaska Margin: Meltwater input, sea level rise, marine productivity, and sedimentary anoxia, Paleoceanography, 26, PA2223, doi:10.1029/2010PA002051.

Doser, D. I., and A. M. Veilleux (2009), A Comprehensive Study of the Seismicity of the Kenai Peninsula-Cook Inlet Region, South-Central Alaska, Bull. Seismol. Soc. Am., 99(4), 2208-2222.

Doser, D. I., A. M. Veilleux, and M. Velasquez (1999), Seismicity of the Prince William Sound Region for over thirty years following the 1964 great Alaskan earthquake, Pure Appl. Geophys., 154, 593-632.

Doser, D. I., N. A. Ratchkovski, P. J. Haeussler, and R. Saltus (2004), Changes in crustal seismic deformation rates associated with the 1964 great Alaska earthquake, Bull. Seismol. Soc. Am., 94, 320-325, doi:10.1785/ 0120030096.

Dumoulin, J. A. (1987), Sandstone composition of the Valdez and Orca Groups Prince William Sound, Alaska, U.S. Geol. Surv. Bull., 1774, 37 pp.

Eberhart-Phillips, D., D. H. Christensen, T. M. Brocher, R. Hansen, N. A. Ruppert, P. J. Haeussler, and G. A. Abers (2006), Imaging the transition from Aleutian subduction to Yakutat collision in central Alaska, with local earthquakes and active source data, J. Geophys. Res., 111, B11303, doi:10.1029/2005JB004240.

Elliott, J. L., C. F. Larsen, J. T. Freymueller, and R. J. Motyka (2010), Tectonic block motion and glacial isostatic adjustment in southeast Alaska and adjacent Canada constrained by GPS measurements, J. Geophys. Res., 115, B09407, doi:10.1029/2009JB007139.

Evans, K. R., P. R. Carlson, M. A. Hampton, M. S. Marlow, and P. W. Barnes (2000), Map of distribution of bottom sediments on the continental shelf, Gulf of Alaska, U.S. Geol Surv. Misc. Field Studies Map 2335.

Finn, S. P. (2012), Megathrust splay fault geometry in Prince William Sound, Alaska, Boise State University, MS Thesis, 148 pp.

Fisher, M. A., and R. Von Huene (1980), Structure of upper Cenozoic strata beneath Kodiak Shelf, Alaska, AAPG Bull., 64(7), 1014-1033.

Fruehn, J., R. von Huene, and M. A. Fisher (1999), Accretion in the wake of terrane collision: The Neogene accretionary wedge off Kenai Peninsula, Alaska, Tectonics, 18, 263-277.

Fuis, G. S., et al. (2008), Trans-Alaska Crustal Transect and continental evolution involving subduction underplating and synchronous foreland thrusting, Geology, 36(3), 267-270.

Fuis, G. S., E. L. Ambos, W. D. Mooney, N. I. Christensen, and E. Geist (1991), Crustal structure of accreted terranes in southern Alaska, Chugach Mountains and Copper River Basin, from seismic refraction results, J. Geophys. Res., 96(B3), 4187-4227. 


\section{LIBERTY ET AL.: MEGATHRUST FAULTS, PRINCE WILLIAM SOUND}

Fujiwara, T., S. Kodaira, T. No, Y. Kaiho, N. Takahashi, and Y. Kaneda (2011), The 2011 Tohoku-Oki Earthquake: Displacement reaching the Trench AxisToshiya, Science, 334, 1240.

Griscom, A., and P. E. Sauer (1990), Interpretation of magnetic maps of the northern Gulf of Alaska, with emphasis on the source of the Slope anomaly, U.S. Geol. Surv. Open File Rep. 90-348, 18 pp.

Hamilton, T. D. (1994), Late Cenozoic glaciation of Alaska, in The Geology of Alaska, The Geology of North America, vol. G-1, edited by G. Plafker and H. C. Berg, pp. 813-844, Geological Society of America, Boulder, Colo., Geol. Soc. Am. Bull.

Helwig, J., and P. Emmet (1981), Structure of the Early Tertiary Orca Group in Prince William Sound and some implications for the plate tectonic history of southern Alaska, J. Alaska Geol. Soc, 1, 12-35.

Ichinose, G., P. Somerville, H. K. Thio, R. Graves, and D. O'Connell (2007), Rupture process of the 1964 Prince William sound, Alaska, earthquake from the combined inversion of seismic, tsunami, and geodetic data, J. Geophys. Res., 112, B07306, doi:10.1029/2006JB004728.

Johnson, J., K. Satake, S. R. Holdahl, and J. Sauber (1996), The 1964 Prince William Sound earthquake: Joint inversion of tsunami and geodetic data, J. Geophys. Res., 101, 523-532.

Kimura, G., Y. Kitamura, Y. Hashimoto, A. Yamagushi, T. Shibata, K. Ujiie, and S. Okamoto (2007), Transition of accretionary wedge structures around the up-dip limit of the seismogenic subduction zone, Earth Planet. Sci. Lett., 255, 471-484, doi:10.1016/j.eps1.2007.01.005.

Lay, T., H. Kanamori, and L. J. Ruff(1982), The asperity model and the nature of large subduction zone earthquakes, Earthquake Predict. Res., 1, 3-71.

Malloy, R. J. (1964), Crustal uplift southwest of Montague Island, Alaska, Science, 146, 1048-1049, doi:10.1126/science.146.3647.1048.

Moore, J. C., T. Byrne, P. W. Plumley, M. Reid, H. Gibbons, and R. S. Coe (1983), Paleogene evolution of the Kodiak Islands, Alaska: Consequences of ridge-trench interaction in a more southerly latitude, Tectonics, 2(3), 265-293.

Moore, J. C., J. Diebold, M. Fisher, J. Sample, T. Brocher, M. Talwani, J. Ewing, R. von Huene, C. Rowe, and D. Stone (1991), EDGE deep seismic reflection transect of the eastern Aleutian arc-trench layered lower crust reveals underplating and continental growth, Geology, 19(5), 420-424.

Nelson, S. W., J. A. Dumoulin, and M. L. Miller (1985), Geologic map of the Chugach National Forest, Alaska: U.S. Geol. Surv. Misc. Field Studies Map $M F-1645 B$, scale 1:250,000, 16 pp.

Oleskovich, D. A., R. D. Hyndman, and K. Wang (1999), The updip and downdip limits to great subduction earthquakes: Thermal and structural models of Cascadia, south Alaska, SW Japan, and Chile, J. Geophys. Res., 104, 14,965-14,992.

Peltier, W. R., and R. G. Fairbanks (2006), Global glacial ice volume and Last Glacial Maximum duration from an extended Barbados sea level record, Quaternary Sci. Rev., 25, 3322-3337.
Plafker, G. (1969), Tectonics of the March 27, 1964 Alaska earthquake, U.S. Geol. Surv. Prof. Pap., 543-I, 74 pp.

Plafker, G., and M. Rubin (1978), Uplift history and earthquake recurrence as deduced from marine terraces on Middleton Island, Alaska, in Proceedings of Conference VI, Methodology for identifying seismic gaps and soon-to-break gaps, U.S. Geol. Surv. Open-File Rep. 78-943, pp. 687-721.

Plafker, G. and J. C. Savage (2010), Near-Field Tsunami Characteristics of Giant Earthquakes in Chile (1960), Alaska (1964), and Sumatra (2004), U.S. Geol. Surv. Open File Rep. 2010-1152.

Plafker, G., J. C. Moore, and G. R. Winkler (1994), Geology of the southern Alaska margin, in The Geology of North America, The Geology of Alaska vol. G-1, edited by G. Plafker and H. C. Berg, pp. 389-449, Geological Society of America, Boulder, Colo.

Reger, R. D. (1991), Deglaciation of the Allison-Sawmill Creeks area, southern shore of Port Valdez, Alaska, Alaska Division of Geological and Geophysical Surveys Professional Report 111, pp. 55-59.

Royer, T. C., J. A. Vermersch, T. J. Weingartner, H. J. Niebauer, and R. D. Muench (1990), Ocean circulation influencing the Exxon Valdez oil spill, Oceanography, 3, 3-10.

Scholz, C. H., and J. Campos (2012), The seismic coupling of subduction zones revisited, J. Geophys. Res., 117, B05310, doi:10.1029/ 2011JB009003.

Sheaf, M. A., L. Serpa, and T. L. Pavlis (2003), Exhumation rates in the St. Elias mountains, Alaska, Tectonophysics, 367(1), 1-11.

Suito, H., and J. T. Freymueller (2009), A viscoelastic and afterslip postseismic deformation model for the 1964 Alaska earthquake, J. Geophys. Res., 114, B11404, doi:10.1029/2008JB005954.

Suleimani, E., R. Hansen, and P. Haeussler (2011), Combined effects of tectonic and landslide-generated tsunami runup at Seward, Alaska during the MW 9.2 1964 earthquake, Pure Appl. Geophys., 168, 1053-1074, doi:10.1007/s00024-010-0228-4.

von Huene, R., and D. Klaeschen (1999), Opposing gradients of permanent strain in the aseismic zone and elastic strain across the seismogenic zone of the Kodiak shelf and slope, Alaska, Tectonics, 18(2), 248-262.

Wang, K., and Y. Hu (2006), Accretionary prisms in subduction earthquake cycles: The theory of dynamic Coulomb wedge, J. Geophys. Res., 111, B06410, doi:10.1029/2005JB004094.

Wilson, F. H., and C. P. Hults (2012), Geology of the Prince William Sound and Kenai Peninsula region, Alaska, U.S. Geol. Surv. Sci. Invest. Map 3110 , 37 pp., 1 sheet, scale 1:350,000.

Zweck, C., J. T. Freymueller, and S. C. Cohen (2002), Three-dimensional elastic dislocation modeling of the postseismic response to the 1964 Alaska earthquake, J. Geophys. Res., 107(B4), 2064, doi:10.1029/ 2001JB000409. 